\title{
DEVELOPMENT OF MEGASONIC CLEANING FOR SILICON WAFERS
}

Quarterly Report No. 3 for September 15-December 14, 1979

By

A. Mayer

January 1,1980

Work Performed Under Contract No. NAS-7-100-955342

RCA Corporation

Solid State Division

Somerville, New Jersey

and

RCA Laboratories

Princeton, New Jersey

\section{MASTER}

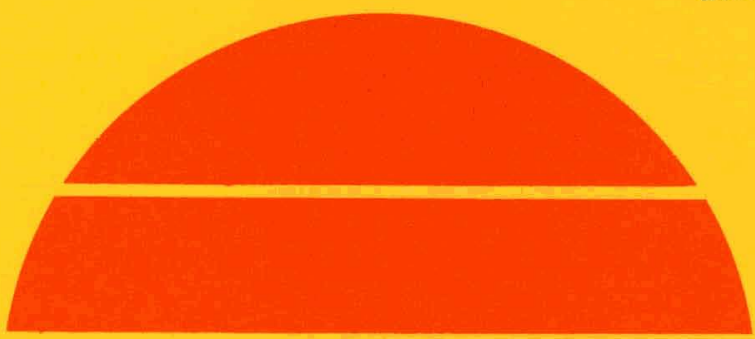

\section{U.S. Department of Energy}




\section{DISCLAIMER}

This report was prepared as an account of work sponsored by an agency of the United States Government. Neither the United States Government nor any agency Thereof, nor any of their employees, makes any warranty, express or implied, or assumes any legal liability or responsibility for the accuracy, completeness, or usefulness of any information, apparatus, product, or process disclosed, or represents that its use would not infringe privately owned rights. Reference herein to any specific commercial product, process, or service by trade name, trademark, manufacturer, or otherwise does not necessarily constitute or imply its endorsement, recommendation, or favoring by the United States Government or any agency thereof. The views and opinions of authors expressed herein do not necessarily state or reflect those of the United States Government or any agency thereof. 


\section{DISCLAIMER}

Portions of this document may be illegible in electronic image products. Images are produced from the best available original document. 


\section{DISCLAIMER}

"This book was prepared as an acoount of woik spunsured by an agency of the United States Government. Neither the United States Government nor any agency thereof, nor any of their employees, makes any warranty, express or implied, or assumes any legal liability or responsibility for the accuracy, completeness, or usefulness of any information, apparatus, product, or process disclosed, or represents that its use would not infringe privately owned rights. Reference herein to any specific commercial product, process, or service by trade namc, trademark, manufacturer, or otherwise, does not necessarily constitute or imply its endorsement, recommendation, or favoring by the United States Government or any agency thereof. The views and opinions of authors expressed herein do not necessarily state or reflect those of the United States Government or any agency thereof."

This report has been reproduced directly from the best available copy.

Available from the National Technical Information Service, U. S. Department of Commerce, Springfield, Virginia 22161.

Price: Paper Copy $\$ 5.00$

Microfiche $\$ 3.50$ 
DRL Line Item. No. 5

\title{
DEVELOPMENT OF MEGASONIC CLEANING FOR SILICON WAFERS
}

\author{
A. Mayer \\ RCA Corporation \\ Solid State Division \\ Somerville, New Jersey 08876 \\ RCA Laboratories \\ Princeton, New Jersey 08540 \\ QUARTERLY REPORT NO. 3 \\ Subcontract under NASA Contract NAS7-100 \\ Task Order No. RD-152 \\ January 1, 1980 \\ The JPL Low-Cost Silicon Solar Array Project is sponsored by the U.S. Department \\ of Energy and forms part of the Solar Photovoltaic Conversion Program to initiate a \\ majur effort toward the development of low-cost solar arrays. This work was perform- \\ ed for the Jet Propulsion Laboratory, California Institute of Technology, by agreement
} between NASA and DOE.

Prepared under Contract No. 955342 for

CALIFORNIA INSTITUTE OF TECHNOLOGY

JET PROPULSION LABORATORY

Pasadena, California 91103 


\section{PREFACE}

This quarterly report covers the work performed by RCA Corporation, Solid State Division (SSD), Princeton and Somerville, New Jersey, for the subcontract under NASA Contract NAS7-100, during the period of 15 September and 14 December 1979.

The contract is being administrated under the direction of Dr. A. H. Firester, RCA Laboratories, Princeton. The program is directed by A. Mayer, SSD, Somerville, New Jersey.

The Technical Monitor for Jet Propulsion Laboratory is Dr. David Moffett. 
Section. Page

I. $\quad \operatorname{ABSTRACT} \ldots \ldots \ldots \ldots \ldots \ldots \ldots \ldots \ldots \ldots \ldots \ldots \ldots \ldots \ldots$

II. TECHNICAL DISCUSSION $\ldots \ldots \ldots \ldots \ldots \ldots \ldots \ldots \ldots \ldots \ldots \ldots \ldots \ldots \ldots \ldots$

A. Megasonic Cleaning Station ................... 2

1. Megasonic Tank, Transducers, and Power Supplies ....... 2

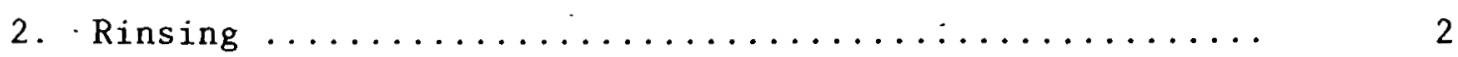

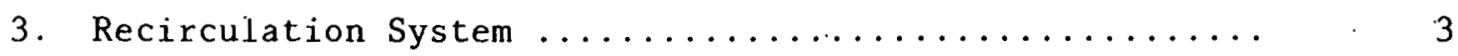

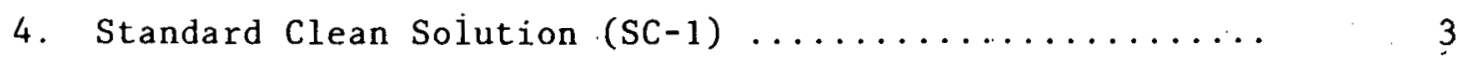

B. Air-Drying System ....................... 4

C: Wafer Carriers and Platens ................... 4

1. Quartz Carriers ......................... 4

2. Polysulfone Carriers and Polyphenyl Sulfide Evaluation . 4

a. Polysulfone ..................... 8

b. Polyphenyl Sulfide ................... 8

3. PTFE Carriers $\ldots \ldots \ldots \ldots \ldots \ldots \ldots \ldots \ldots \ldots \ldots \ldots \ldots$

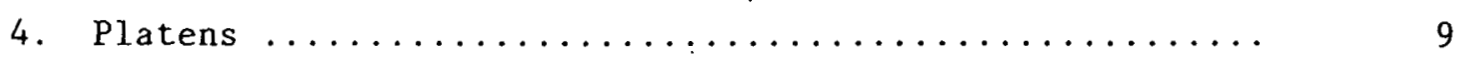

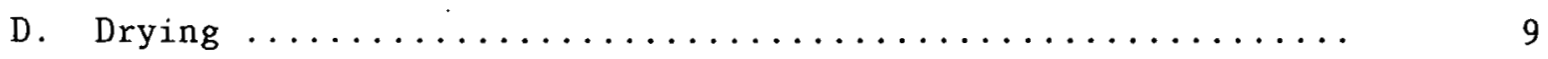

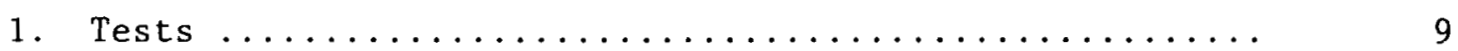

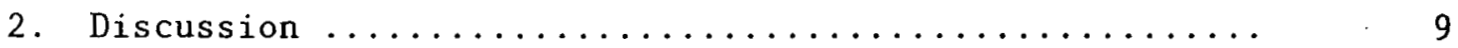

E. Megasonic Cleaning Ability ................... 12

F. Operations Planning of Large-Scale Test .............. 13

1. Operating Instructions . . . . . . . . . . . . . . 13

2. Tasks of Large-Scale Test ................... 13

a. Throughput Rates .................... 13

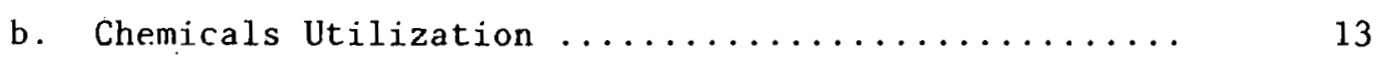

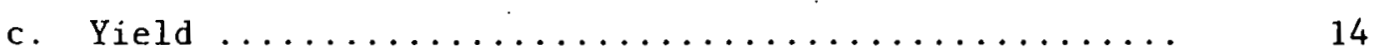

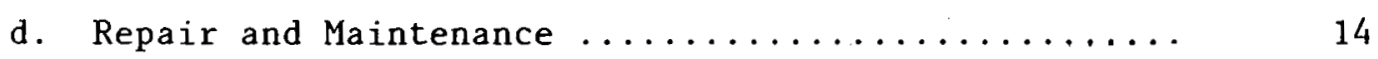

e. Labor, Supervision, and Support Personnel ......... 14

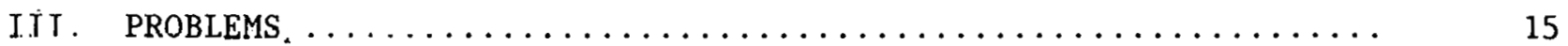

IV. CONCLUSTONS $\Lambda$ ND RECORMENDATIONS $\ldots \ldots \ldots \ldots \ldots \ldots \ldots \ldots \ldots \ldots \ldots \ldots$ 


\section{LIST OF ILLUSTRATIONS}

Figure

1. Shadowgraphs of carrier grooves (31.25X). The first four are quartz carriers; the last two are made of plastic. (a) With 3/16-in. spacing; as received. (b) With 3/16-in. spacing, etched for $2 \mathrm{~h}$ in HF. (c) With 3/16-in. spacing; etched as (b), but then fire-polished. (d) With 3/32-in. spacing; as received. (e) PTFE carrier. (f) Polysulfone carrier ......... 5

2. Platen for three carriers ........................ 10 
SECTION I

ABSTRACT

During this period the total Megasonic system has been operated regularly and is functioning well. The most critical missing part is the belt drive for the air-drying system; delivery of this drive is now scheduled for the end of January. This delay, of about three months, and the prolonged illness of the program director, will cause the program to run longer than planned.

Preliminary data on wafer cleaning and rinsing indicate that the design criteria of cleaning ability, ease of operation, and safety have been largely achieved. Chemicals utilization appears to be even better than anticipated.

Iron has been identified as a contaminant in the rinse system. We believe this to be derived from colloidal ferrous iron in the deionized water. Use of a $0.2-\mu \mathrm{m}$ absolute filter is being tried out for its removal.

The 3/32-in.-spaced quartz carriers were received; the first evaluation indicated that the close spacing does not materially affect the cleaning and drying. More detailed work on cleaning rate is needed, but at this stage it appears that the Megasonic cleaning tank will be capable of making the 2500wafer/hour rate and that the air dryer will come close to this target.

Judged by the wafer scanner, wafers that had been contaminated with $0.3-\mu \mathrm{m}$-diam alumina from aqueous as well as from 1,1,1-trichloroethane/wax suspensions were cleaned successfully. More detailed analysis of apparently high residual contaminants showed the laminar-flow stations to have pockets of high dust count. This can recontaminate slices that were already clean.

Tentative operating instructions for each part of the system are being assembled with a view to working out the plan for testing the system performance on sustained high-rate operation. Although the cleaning unit and the dryer are likely to succeed in dealing with 2500 slices per hour, the transfer, by an operator, from tank to rinse and then to the dryer will become a bottleneck. 


\section{A. MEGASONIC CLEANING STATION}

1. Megasonic Tank, Transducers, and Power Supplies

The failure of two transducer modules after only about 150 duty hours was determined to be caused by a poor ground connection. The vendor is taking steps to solve this problem. While attempting to study the relationship between belt speed, power level, and cleaning ability, we realized that the background (i.e., the best achievable cleanliness) could vary on the laser scanner from less than 10 to over 500 counts over a polished slice of 3-in. diameter. With reproducibility of the scanner known to be about $\pm 6 \%$, a test of the air dryer indicated that exposure to it did not change this count. It became clear that recontamination took place in the Megasonic laminar-flow station. Using a Ciimet; II dust counter we found that there were pockets with counts of 4000-5000 particles $(\stackrel{\geq}{=} 0.5 \mu \mathrm{m}$ in diameter) per cubic foot, both at the entrance to the dryer tunnel and at the holding area near the wafer scanner. After the dryer had been kept running continuously for three days, the air under it showed less than 10

particles $(\stackrel{\geq}{=} 0.3 \mu \mathrm{m}$ in diameter) per cubic foot.

The main problem appears to be caused by curbulence due to the overspill of air from the dryer into the laminar-flow stations. The turbulence can induce room air, laden with dust, to be drawn in. We are conducting experiments. to determine the best way to channel the air flow so as to avoid this effecL.

\section{Rinsing}

After about 120 hours of operation an orange-red stain was found on the lip of the rinse tank where the water spills over in the form of a relatively. thin layer. On analysis, the stain was found to be mainly iron hydroxide. It seems reasonable to theorize that this derived from colloidal ferrous iron in the deionized waler. Ferrous hydroxide would nut registcr ac a epecies rontributing to the conductivity of the water and would not be detectable like an ionized impurity. It is readily oxidized, and the resulting ferric hydroxide

Flimet Corp., Redlands, CA. 
has a very low solubility in an alkaline medium. Thus it would precipitate in the Megasonic station environment, which contains ammonia and hydrogen peroxide droplets. As Millipore Corp. (Bedford, MA) suggested about two years ago that an absolute filter of $2-\mu \mathrm{m}$ pore size be used to remove colloidal iron, such a filter has now been installed. Samples of filtered and unfiltered deionized water for atomic absorption analysis have been taken in an attempt to obtain quantitative data.

During regular operation of the station it has become apparent that the transfer of the platen with three carriers from the Megasonic tank to the rinse tank and from the rinse tank to the dryer is wearisome for an operator. This situation is being reviewed with the objective of devising jigs and fixtures that would help during the trial of the unit in a manufacturing situation. However, this is likely to present a real bottleneck in testing the unit at full capacity.

\section{Recirculation System}

At the presently set recirculation rate of approximately one tank per hour of turnover (about $1 \mathrm{~L} / \mathrm{min}$ ), this system has performed satisfactorily. A pressure gage, protected by a polytetrafluoroethylene (PTFE) diaphragm, has now been fitted and shows that the pressure during pumping has remained constant at about 2-3 psi for about 200 hours of recirculating SC-1 cleaning solution through the $0.2-\mu m$ filter.

\section{Standard Clean Solution $(\mathrm{SC}-1)$}

Tests have shown that there is no need to discard the bulk of the cleaning solution, but that the addition of fresh ammonia and hydrogen peroxide once a day suffices to maintain cleaning ability. One solution has been used in this way tor eight cycles over a period of 10 days with no apparent detriment. This represents a substantial improvement in chemicals utilization.

Assuming a drag-out loss of about $0.2 \mathrm{~mL}$ per wafer, the loss of liquid turns out to be approximately $4 \mathrm{~L}$ per 8 -hour shift. Taking into account the decrease, in that time, in the concentration of ammonia (by evaporation) and of hydrogen peroxide (by decomposition), it appears likely that the addition of $2 \mathrm{~L}$ of each, once per 8-hour shift, will maintain the cleaning ability of SC-1. More precise figures, as well as an indication of the buildup of soluble impurities, can be obtained only by trial on a larger scale. For calculating efficiencies and 
costs we assume that 100,000 slices can be cleaned before the SC-1 solution needs to be discarded.

\section{B. AIR-DRYING SYSTTEM}

The air-drying system was operated by pushing the carriers through manually. Delivery of the belt-drive system has been further delayed and is now expected at the end of January 1980. Pushing wafers through by hand does not seem to cause a major increase in particles but undoubtedly increases the background and the chance for spurious contamination. The system was checked with a particle counter and found to be contaminated at both ends. Dust counts reached up to 5000 particles, $\stackrel{\geq}{=} 0.5 \mu \mathrm{m}$ in diameter, per cubic foot. By contrast, the particle count was essentially zero in the air stream at a setting of $0.3-\mu \mathrm{m}$ diameter or greater.

On a few occasions, after the system had been shut down over weekends, high particle counts were registered. Since then, the system has been kept on at all time. No increase in backpressure (approximately 0.5 in. W. G.) has been noted, and we conclude that the system is satisfactory. The only change to be made will be installation of a high-low switch so that power can be conserved by keeping the airflow going during idle times at less than maximum rate. Experiments are under way to trace the airflow coming out of each end of the tunnel and to modify it so as to minimize the induction of dust-laden laboratory air.

\section{WAFER CARRIERS AND PLATENS}

\section{Quartz Carriers}

The new carriers with 3/32-in. spacing and a groove width of nominally $0.040 \mathrm{in.}$ ( $1 \mathrm{~mm}$ ) have been tested (see Section II.C.4, below) and found satisfactory. In view of these data, the grooves of all types of carriers have been measured by means of a shadowgraph (Fig. 1).

Comparison of these data shuws lhat clearance becwecn wafur and gronve wall. is critically important and that surface texture and wettability also play a part.

2. Polysulfone Carriers and Polyphenyl Sulfide Evaluation

Quartz carriers are expensive and fragile. In an attempt to reduce the cost, a search was made for a plastic material that could be used as a slice 

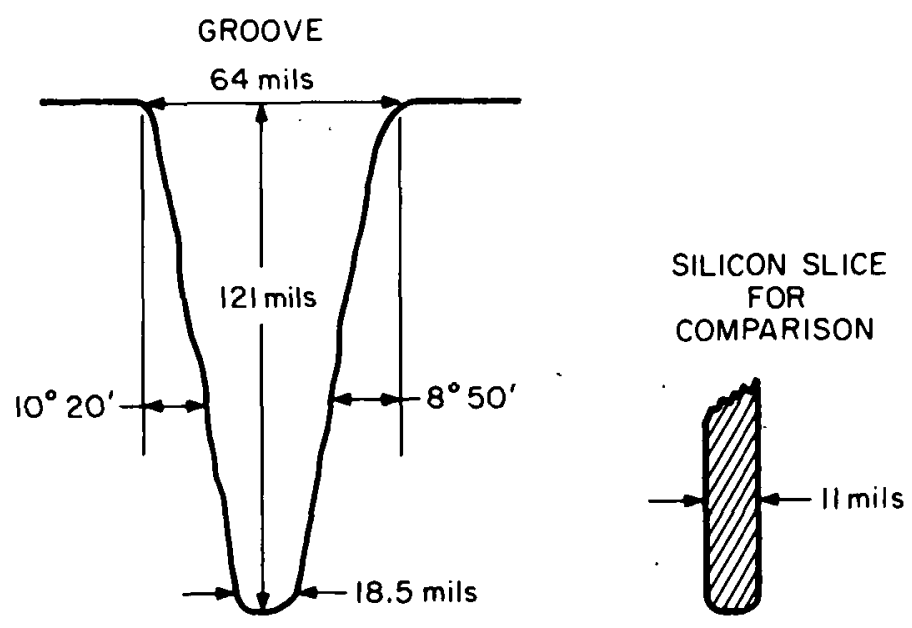

(a) With $3 / 16-i n$. spacing; as received.

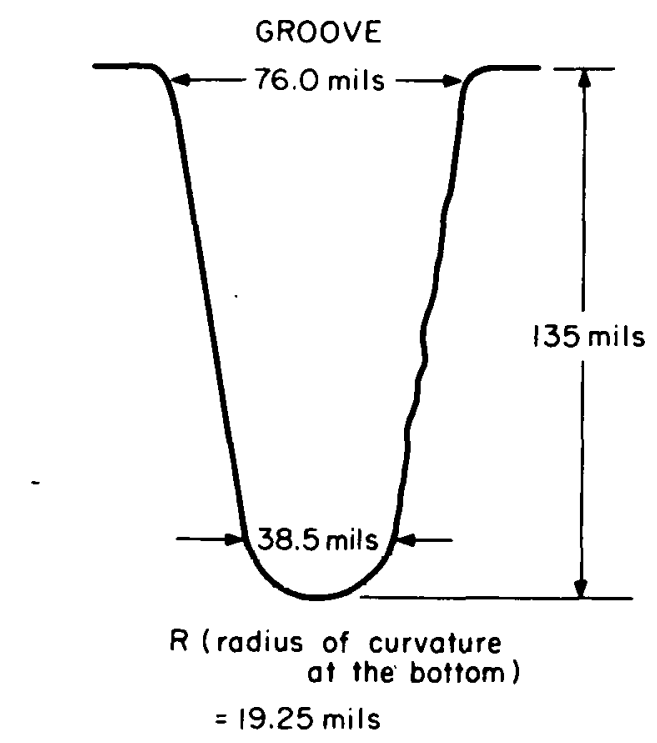

(b) With 3/16-in. spacing, etched for $2 \mathrm{~h}$ in $1 \mathrm{IT}$.

Figure 1. Shadowgraphs of carrier grooves (31.25X). The first four are quartz carriers; the last two are made of plastic. 


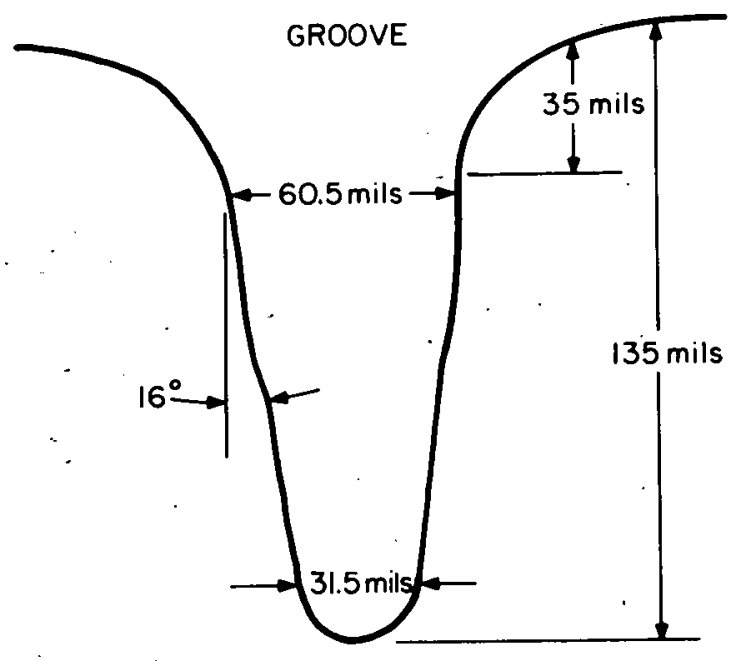

(c) With 3/16-in. spacing; etched as (b), but then fire-polished.

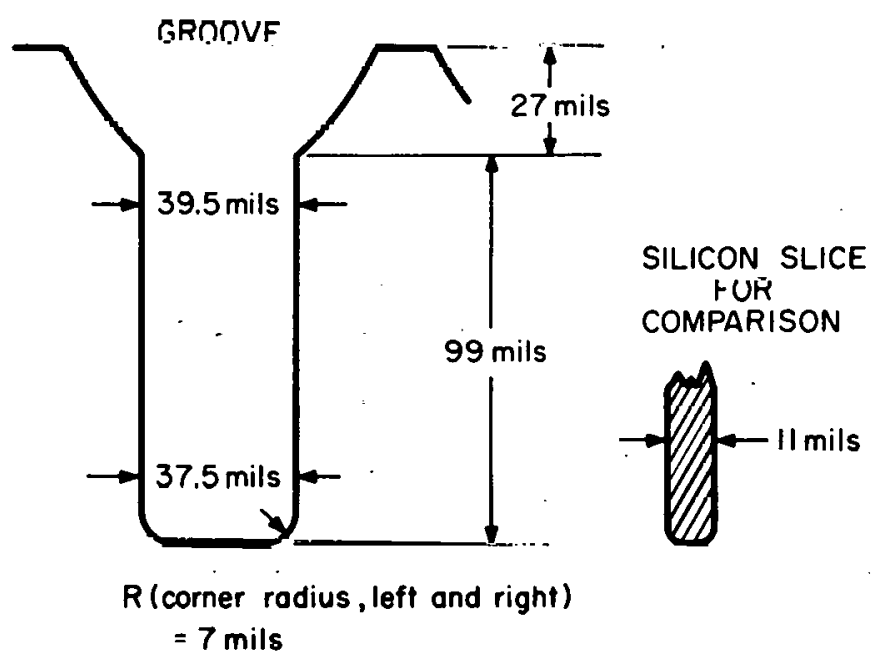

(d) With $3 / 32-$ in. spacing; as rereived. 


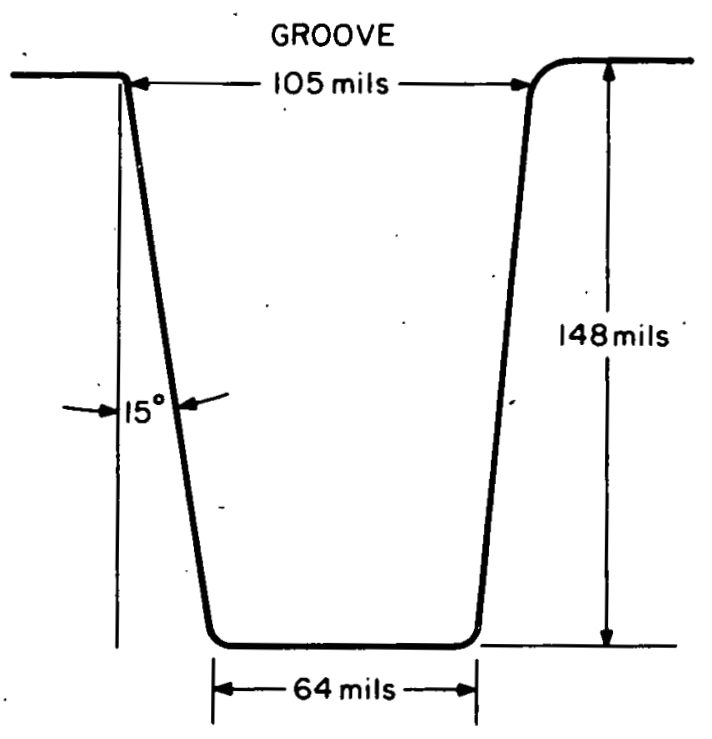

(e) PTFE carrier.

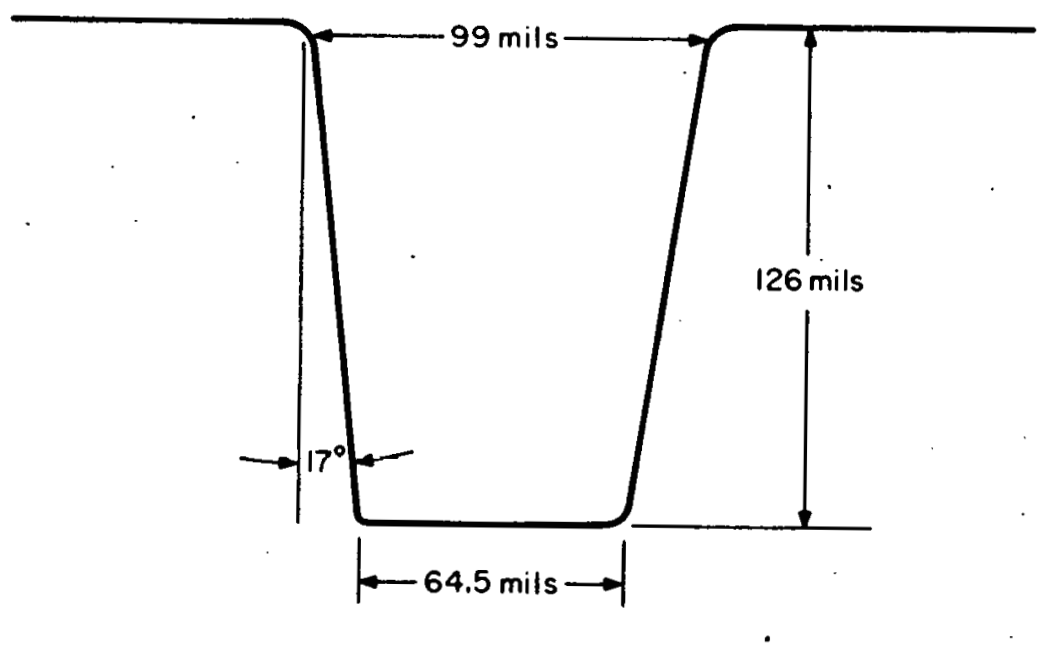

(f) Polysulfone carrier. 
carrier up to the final stage of solar-cell production (anneal/diffusion) and also for the large-scale test of the Megasonic system.

a. Polysulfone

Polysulfone, because of its wetting properties, was a likely candidate materiali: It performed well in corrosion tests with SC-1. Three carriers were purchased that. had been fabricated from machined parts. These were assembled with threads and screws and had a groove width of 0.06 in.

$(1.5 \mathrm{~mm})$. The manufacturer reported that the material was difficult to machine and that the grooves were rough-textured. Shot blasting improved this slightly. In view of the relatively slight advantage of polysulfone over PTFE (polytetrafluoroethylene) in terms of wettability and possibly in ease of molding, the major expenditure of purchasing a mold at this stage seems unjustified. In addition, the material is attacked by many solvents so that carriers can be used in degreasing or photonresist nperatinns nnly after careful selection of the solvents to be employed. It was therefore decided not to experiment any further with this material.

b. Polyphenyl Sulfide

A suggestion was made by a company that specializes in the experimental. molding of plastics to use the polyphenyl sulfide plastic Ryton, made by Phillips Petroleum Co., Chemicals Division (Bartlesville, OK). This is thought to be chemically more inert than polysulfone. Accordingly, some test pieces of Ryton 4 and 10 were corrosion tested. These did not hold up in warm sulfuric acidhydrogen peroxide solution, as used in system " $Z$ " cleaning. In $\mathrm{SC}-1$ at about $50^{\circ} \mathrm{C}$ for 89 hours, they showed a slight weight gain of approximately $0.1 \%$ and no physical signs of attack.

The test solution was then analyzed and found to contain levels of calcium, magnesium, sodium, aluminum, boron, and silicon significantly greater than the blank solution, treated similarly but without test pieces. As Ryton is glassfilled, the data suggest. that this filling is leachahle. In a recirculating solution, as used in the Megasonic system, this would lead to a buildup of soluble ions undesirable for this project. No further work is planned.

\section{PTFE Carriers}

Twenty-five PTFE carriers with 3/16-in. spacing and with 0.06-in. groove width were received. This is sufficient for the large-scale test; the wide 
groove spacing, however, may prevent us from achieving the 2500-wafers/hour target rate, which is based on $3 / 32-i n$ spacing.

4. Platens

The PTFE platen designed for the quartz carriers can also be used for the PTFE carriers with a minor modification, i.e., removal of a pair of stops. The platen is shown in Fig. 2 .

D. DRYING

1. Tests

Even though the belt drive for the drying tunnel has not been received, drying rates can be obtained by manual operation. These rates are not very precise but can give a good indication of probable performance.

Calculations show that to achieve a drying rate of 2500 slices/hour with the existing equipment, when the 3/32-in.-spaced quartz carriers are used, the belt speed has to be $12.75 \mathrm{~cm} / \mathrm{min}$. This is equivalent to a drying time of four minutes, the time it takes the carrier to enter the dryer and then to clear it completely.

The drying tests with various carriers were made as follows: The carriers were loaded with 11-mil-thick 3-in.-diam slices, cleaned Megasonically in SC-1, and rinsed; then each carrier was dried between dummies loaded with wafers to ensure equal air flow distribution. Each wafer was inspected for dryness, and the state of the carrier was also noted. The temperature was $65^{\circ} \mathrm{F}$ and the relative humidity, $20 \%$. The results are given in Table 1 .

\section{Discussion}

The only difference between the 3/16-in.- and the 3/32-in.-spaced quartz carriers, as received, is the groove shape. Clearly, the tapered round-ended groove leaves too little clearance between the wall and the slice for the force of the air to overcome the capillary force that holds water in this region. The square groove of the 3/32-in. carrier dries out most rapidly. In fact, as can be seen from Table 1 , the drying time can be reduced to three minutes. This is equivalent to a drying rate of about 3300 wafers/hour when the 3/32-in.-spaced carrier is used, or approximately 1650 wafers/hour with the 3/16-in.-spaced carrier. 


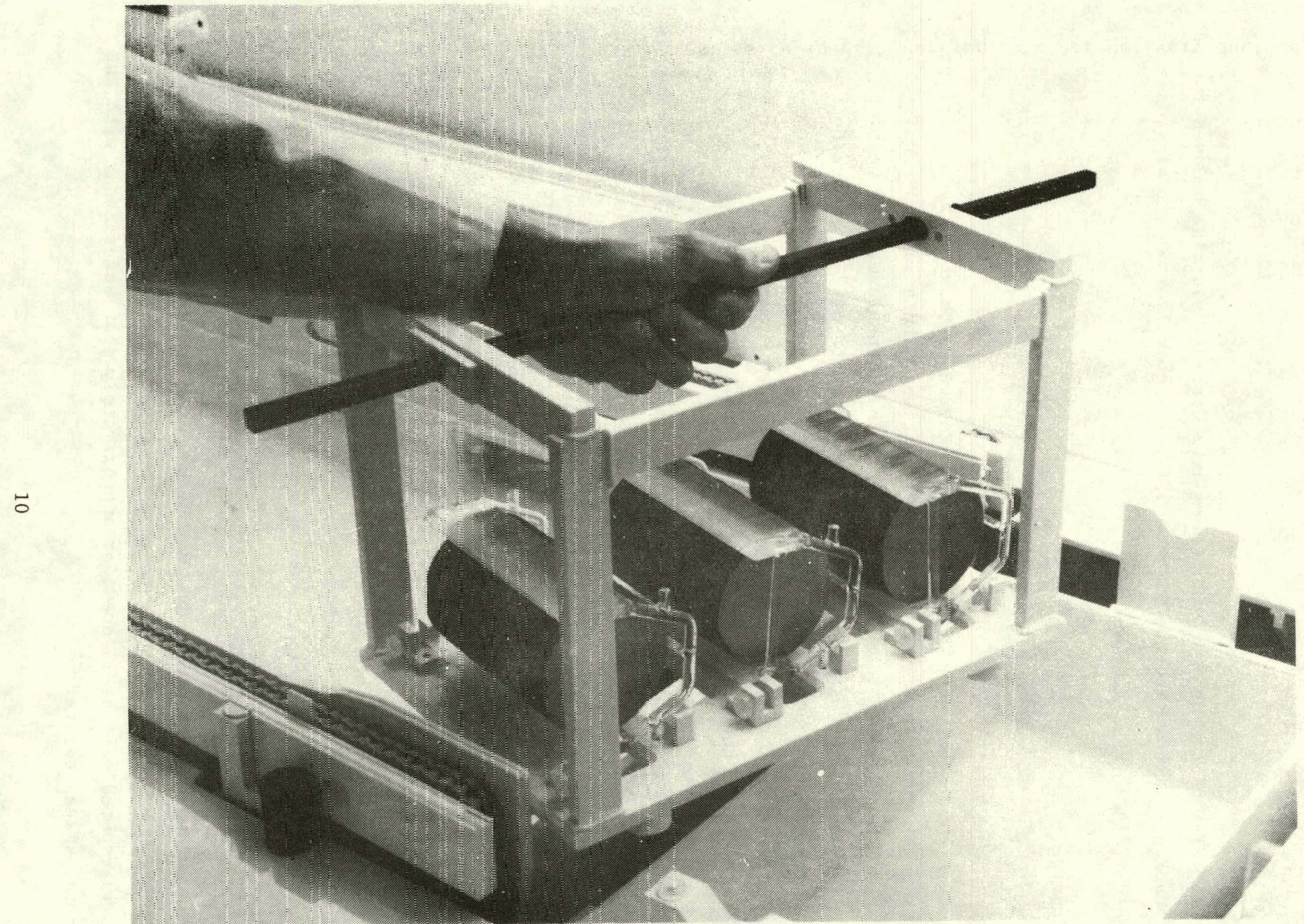

Figure 2. Platen for three carriers. 
TABLE 1. COMPARISON OF DRYING TIMES WITH DIFFERENT CARRIERS

\begin{tabular}{|c|c|c|c|c|c|c|c|c|c|c|}
\hline \multirow[b]{2}{*}{ Material } & \multirow{2}{*}{ Figure } & \multirow{2}{*}{$\begin{array}{c}\text { Slice } \\
\text { Spacing }\end{array}$} & \multirow{2}{*}{$\begin{array}{r}\text { Groove } \\
\text { Shape } \\
\end{array}$} & \multirow{2}{*}{$\begin{array}{r}\text { Groove } \\
\text { Width }\end{array}$} & \multirow{2}{*}{$\begin{array}{c}\text { Groove } \\
\text { Surface } \\
\text { Condition } \\
\end{array}$} & \multirow{2}{*}{$\begin{array}{l}\text { Drying* } \\
\text { Time } \\
\text { (min) } \\
\end{array}$} & \multicolumn{2}{|c|}{ Comments } & & \multirow{2}{*}{$\begin{array}{c}\text { Equivalent } \\
\text { Drying } \\
\text { Rate } \\
\text { (slices } / \mathrm{h}) \\
\end{array}$} \\
\hline & & & & & & & Slice & Groove & & \\
\hline Quartz & $1(d)$ & $3 / 32$ & Square & $0.0395-0375$ & $\begin{array}{l}\text { Diamond } \\
\text { Ground }\end{array}$ & 4 & Dry & Dry & - & 2500 \\
\hline Quartz & $1(d)$ & $3 / 16$ & Square & $0.0395-0375$ & $\begin{array}{l}\text { Diamond } \\
\text { Ground }\end{array}$ & 4 & Dry & Dry & & 1250 \\
\hline Quartz & $\cdot 1(d)$ & $3 / 32$ & Square & $0.0395-0375$ & $\begin{array}{l}\text { Diamond } \\
\text { Ground }\end{array}$ & 3 & Dry & Dry & r & 3300 \\
\hline Quartz & $1(\mathrm{~d})$ & $3 / 16$ & Square & $0.0395-0375$ & $\begin{array}{l}\text { Diamond } \\
\text { Ground }\end{array}$ & 3 & Dry & Dry & & 1650 \\
\hline Quartz & $1(\mathrm{~d})$ & $3 / 32$ & Square & $0.0395-0375$ & $\begin{array}{l}\text { Diamond } \\
\text { Ground }\end{array}$ & $21 / 2$ & $\begin{array}{l}24 / 25 \\
\text { Dry }\end{array}$ & $24 / 25$ & Dry & $\sim 4000$ \\
\hline Quartz & $1(d)$ & $3 / 16$ & Square & $0.0395-0375$ & $\begin{array}{l}\text { Diamond } \\
\text { Ground }\end{array}$ & $21 / 2$ & $\begin{array}{l}12 / 13 \\
\text { Dry }\end{array}$ & $12 / 13$ & Dry & $\sim 2000$ \\
\hline Quartz & $1(\mathrm{a})$ & $3 / 16$ & Taper & $0.064-0.018$ & $\begin{array}{l}\text { Diamond } \\
\text { Ground }\end{array}$ & 4 & Wet & Wet & & $<1250$ \\
\hline Quartz & $\cdot 1(b)$ & $3 / 16$ & Taper & $0.076-0.0385$ & $\mathrm{HF}$ & 4 & Wet & Wet & & $<1250$ \\
\hline Quartz. & $1(\mathrm{c})$ & $3 / 16$ & Taper & $>0.075-0.0315$ & $\begin{array}{l}\mathrm{HF} \text { and } \\
\text { Firepolish }\end{array}$ & 4 & Wet & Wet & & $<1250$ \\
\hline PTFE & $1(\mathrm{e})$ & $3 / 16$ & $\begin{array}{l}\text { Square } \\
\text { Taper }\end{array}$ & $0.105-0.064$ & Machined & 4 & Dry & Some $h$ & vet & $<1250$ \\
\hline PTFE Repeat & $1(\mathrm{e})$ & $3 / 16$ & $\begin{array}{l}\text { Square } \\
\text { Taper }\end{array}$ & $0.105-0.064$ & Machined & 4 & Dry & Dry & & 1250 \\
\hline PTFE Repeat & $1(\mathrm{e})$ & $3 / 16$ & $\begin{array}{l}\text { Square } \\
\text { Taper }\end{array}$ & $0.105-0.064$ & Machined & 4 & Dry & $24 / 25$ & Dry & $\sim 1250$ \\
\hline Polysulfone & $1(\mathrm{f})$ & $3 / 16$ & $\begin{array}{l}\text { Square } \\
\text { Taper }\end{array}$ & $0.099-0.0645$ & Machined & 4 & Dry & Dry & & 1250 \\
\hline Polysulfone & $1(\mathrm{f})$ & $3 / 16$ & $\begin{array}{l}\text { Square } \\
\text { Taper }\end{array}$ & $0.099-0.0645$ & Machined & $31 / 2$ & $\begin{array}{l}24 / 25 \\
\text { Dry }\end{array}$ & Few We & et & 1430 \\
\hline Polysulfone & $1(f)$ & $3 / 16$ & $\begin{array}{l}\text { Square } \\
\text { Taper }\end{array}$ & $0.099-0.645$ & Machined & 3 & Wet & Wet & & $<1650$ \\
\hline
\end{tabular}

*Drying time $=$ Entry of first slice to exit of last slice in each carrier into air delivery duct region: $\mathrm{HF}=$ Etched in $48 \%$ hydrofluoric acid for two hours. 
A comparison between the quartz carriers [see Figs. 1(a) through 1(d)] shows that merely widening the groove is not decisive, but that the square shape is. This indicates that the contact between the rim of the slice and the end of the groove must be minimized to reduce the capillarity in that region to a minimum and to allow as much access of air as possible.

This is further borne out by the observation that drying in the squaregrooved PTFE and polysulfone carriers is achievable in four minutes. However, it must be noted that these carriers have even wider (approx. 0.06-in.) grooves. PTFE can be seen to have retained some water in the grooves after four minutes, even though the slices were dry.

\section{E. MEGASONIC CLEANING ABILITY}

We had previously reported that slices deliberately contaminated with aqueous alumina suspensions could be cleaned and that the particle count on the wafer surface then reverted to that found before contamination.

Wafers also were deliberately contaminated with $5 \mathrm{~g} / \mathrm{L}$ of $0.3-\mu \mathrm{m}$-diam alumina suspended in 1,1,1-trichloroethane (1-1-1 TCE) containing $10 \mathrm{~g} / \mathrm{L}$ of "Liquid Mounting Wax" (Semimetals Corp., Mountainview, CA), used to mount silicon wafers during polishing. The wafers were dipped into this solution, rinsed with 1-1-1 TCE, dried, rinsed with water, and spun dry before Megasonic cleaning. Other sets of wafers were contaminated with a suspension of $1 \mathrm{~g} / \mathrm{L}$ of $0.3-\mu \mathrm{m}$-diam alumina in water, followed by rinsing and drying. In a 1 cases these contaminated wafers showed particle counts of about 20,000 and could be cleaned to background levels of less than 200. A few wafers could not be cleaned to counts of less than 500. There was no difference between the aqueous or wax-solvent contaminated wafers.

It seems that the removal of major contaminants such as the alumina mentioned above, even when the contaminants are allowed to dry overnight, can be carried out at belt speeds hetween 4 and $10 \mathrm{~cm} / \mathrm{min}$ undcr maximum availahle power from ovcr $2 n$, nnO counbs lo a few hundred. Recent work showed that some recontamination is taking place. As pointed out earlier, we are analyzing the hood for dust count and making changes to baffling and laminarflow conditions to eliminate this source of rontamination. Becausc of this uncertainty, further work on the relationship between power, speed, and cleaning ability has been postponed temporarily. 


\section{F. OPERATIONS PLANNING OF LARGE-SCALE TEST}

\section{Operating Instructions}

Operating instructions for each piece of equipment are being collected, either from the manufacturer or as worked out during the tests of the system in this laboratory. Calibrations, such as belt speed, are attached directly to the machines.

2. Tasks of Large-Scale Test

a. Throughput Rates

It is relatively simple to arrive at maximum throughput rates for the Megasonic unit, the rinse tank, and the air dryer. Apparently the use of 3/32-in.-spaced carriers will make it possible to achieve the projected rates of 2500 wafers/hour. For economic reasons, however, the PTFE carriers are the ones to be used in the rate lest. These have 3/16-in: spacing because they were ordered so they would be available in time for the large-scale test before the idea of closer spacing could be tested.

Another problem in the determination of maximum rates is likely to be the transfer from the Megasonic tank to the rinse tank and hence to the dryer. Even with good fixturing an operator will probably not be capable of sustaining a high-speed effort. In a full-scale production plant this problem can be solved by the use of mechanical transfer methods. Suitable equipment is commercially available, but cannot be incorporated into the existing unit because of space limitations.

b. Chemilals Utilization

Preliminary work has shown that chemicals conservation can be achieved by the periodic addition of the concentrated solution of each of the chemicals. There appears to be no problem in generating these data by putting slices through the system in batches of five platens, each with three carriers containing 25 slices, i.e., a total of 375 slices, and to recycle these after exposure to room air.

The measurements to be obtained are to include the amount of solution required to make up for drag-out and to ascertain whether this is sufficient to balance the loss of ammonia by evaporation and of hydrogen peroxide by decomposition. 
It is also proposed to use copper and sodium as indicator elements to monitor the buildup of soluble impurities.

c. Yield

First, it is proposed to keep a record of breakage to determine the physical yield; second, to set limits for cleanliness, based on the laser scanner experience, and to use a polished control wafer to monitor the cleanliness of each carrier. These measures will generate a quality yield figure.

d. Repair and Maintenance

By keeping a rccord of opesaling hours versus equipment failure and also downtime fur repa1r, these requirements can be determined with reasonable accuracy, provided the operating period is sufficiently extended.

e. Labor, Supervision, and Support Personnel

In view of the throughput limitations these factors will probably have to be best estimates for a plant laid out to optimize personnel utilization. 


\section{SECTION III}

\section{PROBLEMS}

1. The extended time for delivery of the belt drive and the prolonged absence of the program director, due to iliness, are causing a delay in the program.

2. In reviewing, the operations for the large-scale test we find that the maximum rate can be demonstrated readily for each piece of the system, but that the total operation will be restricted by the transfers from the cleaning tank to the rinse tank and to the dryer. This program also impacts the true time requirements for operator and support personnel. It may be possible to make good estimates of these data by considering equipment capable of effecting mechanical transfer in a large-scale plant dedicated to the manufacture of solar cells. 


\section{SECTION IV}

\section{CONCLUSIONS AND RECOMMENDATIONS}

1. Apparently the use of quartz carriers with 3/32-in.-spaçed, square-shaped grooves makes it possible to attain the target cleaning rate of 2500 wafers/hour.

2. The rate of drying with the cold-air dryer and the same 3/32-in.-spaced carriers is close to 3300 wafers/hour.

3. A production bottleneck is likely to develop in the transfer stages from Megasonic tank to rinse tank and from rinşe tank to dryer.

4. A source of contamination with iron has been identified. The model suggests that this is colloidal ferrous iron in the deionized water. An attempt to cope with this by use of a $0.2-\mu \mathrm{m}$ filter is being evaluated.

5. The RCA laser scanner is an excellent tool, not only for the rapid assessment of changes made in the cleaning process but also as an instrument for production control.

6. Sources of contamination with dust from laboratory air inducted by turbulence have been identified, and steps to reduce this effect taken.

7. Tests with slices deliberately contaminated with alumina and also with wax-contaminated alumina of $0.3-\mu \mathrm{m}$-diam particle size indicated that Megasonic cleaning was effective.

8. Owing to the extended delivery time for the dryer belt, the large-scale test will have to be started later than planned.

9. It is recommended to continue this program as planned, but to delay the large-scale test until after the dryer belt drive has been installed and evaluated in the Somerville location. 